\title{
CLEANER LEATHER TANNING PROCESS USING GAMBIR: THE INFLUENCE OF REBATING ON THE PROPERTIES OF LEATHER
}

\section{Gresy GRIYANITASARI ${ }^{1 *}$, Dona RAHMAWATI ${ }^{1}$, SUGIHARTONO ${ }^{1}$, Yuny ERWANTO ${ }^{2}$}

${ }^{1}$ Center for Leather, Rubber, and Plastics, Ministry of Industry, Jl. Sokonandi no. 9 Yogyakarta 55166, Indonesia

${ }^{2}$ Department of Animal Product Technology, Faculty of Animal Science, Universitas Gadjah Mada Jl. Flora No. 1,

Bulaksumur Yogyakarta 55281, Indonesia

Received: 23.08 .2019

Accepted: 28.11.2019

https://doi.org/10.24264/Ifj.19.4.6

CLEANER LEATHER TANNING PROCESS USING GAMBIR: THE INFLUENCE OF REBATING ON THE PROPERTIES OF LEATHER

ABSTRACT. Gambir (Uncaria gambir) is a traditional plant from West Sumatera, Indonesia. Containing condensed tannin, gambir could be used as vegetable tanning agent in the leather making process. Sheepskin is usually used as materials for garment leather. Some industries in Indonesia use pickled sheepskin as raw material for the next process that the previous bating process is uncontrolled. Therefore, this study aims to determine the effect of rebating in the repickle stage on the leather tanned with Uncaria gambir. For alum-gambir tanned leather, rebating increased its softness, tear strength, and hydrothermal stability, while for glutaraldehyde-gambir tanned leather, rebating increased its tensile strength, degree of tannage, and tannin bound. The broad DSC peak revealed that the distribution of collagen molecules of all samples was unequal. Rebating could increase and decrease the quality of leather.

KEY WORDS: sheep leather, bating, vegetable tanning, gambir

UN PROCES DE TĂBĂCIRE A PIELII MAI CURAT PRIN UTILIZAREA GAMBIRULUI: INFLUENTA RESĂMĂLUIRII ASUPRA PROPRIETĂTILOR PIELII REZUMAT. Gambirul (Uncaria gambir) este o plantă tradiţională din Sumatra de Vest, Indonezia. Datorită conţinutului de tanin condensat, gambirul poate fi utilizat ca agent de tăbăcire vegetală în procesul de fabricare a pielii. Pielea de oaie este folosită de obicei ca materie primă pentru îmbrăcămintea din piele. Unele industrii din Indonezia folosesc piele de oaie piclată ca materie primă pentru următorul proces, aşadar procesul de sămăluire anterior este necontrolat. Prin urmare, acest studiu îşi propune să determine efectul resămăluirii în etapa de repiclare asupra pielii tăbăcite cu Uncaria gambir. În cazul pielii tăbăcite cu alaun şi gambir, resămăluirea a condus la creşterea moliciunii, rezistenţei la sfâşiere şi stabilităţii hidrotermice, în timp ce în cazul pielii tăbăcite cu glutaraldehidă şi gambir, resămăluirea a condus la creşterea rezistenţei la rupere, gradului de tăbăcire şi o mai bună legare a taninului. Picul larg evidenţiat prin analiza DSC a arătat că distribuţia moleculelor de colagen a fost inegală în cazul tuturor probelor. Resămăluirea poate duce fie la creşterea, fie la scăderea calităţii pielii.

CUVINTE CHEIE: piele de oaie, sămăluire, tăbăcire vegetală, gambir

UN PROCÉDÉ DE TANNAGE DU CUIR PLUS ÉCOLOGIQUE UTILISANT LE GAMBIR: L'INFLUENCE DU RE-CONFITAGE SUR LES PROPRIÉTÉS DU CUIR RÉSUMÉ. Le gambir (Uncaria gambir) est une plante traditionnelle de Sumatra occidental, en Indonésie. Contenant du tanin condensé, le gambir pourrait être utilisé comme agent de tannage végétal dans le processus de fabrication du cuir. La peau de mouton est généralement utilisée comme matériau pour les vêtements en cuir. Certaines industries indonésiennes utilisent la peau de mouton picklée comme matière première pour le processus suivant, de sorte que le processus de confitage précédent est incontrôlé. Par conséquent, cette étude a pour objectif de déterminer l'effet du re-confitage dans l'étape de repicklage sur le cuir tanné à l'Uncaria gambir. Pour le cuir tanné à l'alungambir, le re-confitage a augmenté sa douceur, sa résistance à la déchirure et sa stabilité hydrothermale, tandis que pour le cuir tanné au glutaraldéhyde-gambir, le re-confitage a augmenté sa résistance à la traction, son degré de tannage et le tanin lié. Le large pic de DSC a révélé que la distribution des molécules de collagène de tous les échantillons a été inégale. Le re-confitage peut également augmenter et diminuer la qualité du cuir.

MOTS CLÉS : cuir de mouton, confit, tannage végétal, gambir

\footnotetext{
* Correspondence to: Gresy GRIYANITASARI, Center for Leather, Rubber, and Plastics, Ministry of Industry, Jl. Sokonandi No. 9 Yogyakarta 55166, email: gresygriyanitasari@gmail.com
} 


\section{INTRODUCTION}

Gambir (Uncaria gambir) is one of the traditional export plants from West Sumatera, Indonesia [1] that is traditionally used as vegetable tanning agent because it contains condensed tannin [2]. Gambir plant could be extracted by boiling the leaves and branches, then pressing it to take the gum out [1, 3]. Based on the percentage of tannin content, gambir has several kinds, such as coin, superior, brown cube, and galamai (black cube) [4]. Heating gambir could increase the solubility of tannin [5] and change catechin into tannin since the catechin loss the water molecules and the monomers are combined into tannin [4].

Nowadays, people are more concerned about the effect of industry on the environment and health [6] that makes them search the possibility of using plant materials $[7,8]$. Some research was conducted to find the application of gambir as leather tanning agent. Kasim et al. [9] has tanned goat leather using gambir combined with alum to find the best concentration. His study found that the best result was generated by $3 \%$ of alum as pretanning agent and 3\% of gambir as tanning agent because it has the highest degree of tannage and tannin bound. Another study of gambir showed that gambir has different characterization that caused different quality of tanned leather [3]. That study collected ten gambir from ten different locations, analyzed the characteristics, and applied as tanning agent for leather. The result concluded that the higher the tannin content of gambir, the higher degree of tannage of the leather, and the higher catechin content of gambir, the lower tannin bound of the leather.

Sheepskin is relatively small with $0.8 \mathrm{~mm}$ thickness [10] and commonly used for garment (jacket, coat, skirt, and pants). Among other animal skins, sheepskin was softer and more luxurious. To be made into garment that comes directly into contact with human skin, it needs to be processed using safe materials to replace chrome. Gambir is plant based material that could be used as natural tanning agent.

Leather tanning is a process to 'cook' raw skin into leather that consists of several stages: soaking, unhairing, liming, deliming, bating, pickling, tanning, dyeing, fatliquoring, and drying. After pickling stage, pickled sheep leather could be kept in a certain time. Processing pickled sheep leather means that the tanneries could not control the previous pre-pickling stages (usually called beamhouse stages). Bating stage is a stage in the leather tanning process where non-structural proteins from skins removed by protease that open up the structure of the collagen fiber and ease the fiber waves [11, 12]. Mostly, protease enzyme is produced from microorganism that contains no hazardous materials [13]. By adding more bating agent in the leather making process, more interfibrillary substances could be removed [11] that affect the physical properties [12], the penetration of tanning agent [14], and thermal stability. Therefore, this study determined the effect of rebating in the repickle stage on the leather tanned with gambir.

\section{EXPERIMENTAL}

\section{Materials}

Raw materials used in this research are processed pickled sheepskins from Sleman, Yogyakarta. Gambir used in this study is black cube gambir sourced from Sumatera Barat, Indonesia. Black cube gambir (pale catechin) is known as gambir extract that already proceeds. Chemicals used for the leather tanning process were of commercial grade from a chemical reseller in Yogyakarta.

Table 1: Samples description

\begin{tabular}{cl}
\hline Sample Identification & \multicolumn{1}{c}{ Description } \\
\hline Gam-Al & Alum - gambir tanning combination without rebating \\
Gam-Alx & Alum - gambir tanning combination with rebating \\
Gam-Glu & Glutaraldehyde - gambir tanning combination without rebating \\
Gam-Glux & Glutaraldehyde - gambir tanning combination with rebating \\
Gam & Gambir tanning without rebating \\
Gamx & Gambir tanning with rebating \\
\hline
\end{tabular}


Once received from the seller in Bantul, Yogyakarta, Indonesia, pickled sheep skin was rebated. The rebating formulation is described in Table 2. The percentage of the product was calculated based on the pelt weight. In this process, the sheepskin was added with $8 \%$ of salt and $80 \%$ of water and ran for 20 minutes in the rotating drum (Otto Specht serial number $80304)$. After that, $1 \%$ of bating agent for the acid bate was added and ran for 60 minutes.

Table 2: Formulation of rebating process

\begin{tabular}{cccc}
\hline Process & Product & $\%$ & Duration (min) \\
\hline Rebating & Salt & 8 & 20 \\
& Water & 80 & \\
& Feliderm Bate AB, Clariant & 1 & 60 \\
\hline
\end{tabular}

Rebated sheepskins were then subjected to the formulation shown in Table 3. This formulation was modified formula from Musa et al. [7] and Sreeram et al. [15]. Similar with the Table 2, the percentage of the product in Table 3 was calculated based on the pelt weight.

Table 3: Formulation of the tanning process

\begin{tabular}{|c|c|c|c|}
\hline Process & Product & $\%$ & Duration (min) \\
\hline \multirow{3}{*}{ Repickle } & Salt & 10 & \multirow{2}{*}{10} \\
\hline & Water & 80 & \\
\hline & Sodatan SB, Selic chemical company & 2 & 30 \\
\hline \multirow{2}{*}{ Pretanning } & Sodatan TSN, Selic chemical company & 2 & 30 \\
\hline & Tannit LSW, Dr Bohme & 0,5 & 30 \\
\hline Tanning & Gambir extract & 25 & $4 \times(30 \varnothing 15)$ \\
\hline Tanning combination & Alum/glutaraldehyde & 6 & 60 \\
\hline \multicolumn{4}{|c|}{ Drained, aged, and shaved } \\
\hline \multirow{3}{*}{ Wetting back } & Water & 200 & \multirow{3}{*}{30} \\
\hline & Wetting agent & 0,5 & \\
\hline & Oxalic acid & 0,3 & \\
\hline \multirow[t]{5}{*}{ Neutralization } & Water & 150 & \multirow{3}{*}{60} \\
\hline & Novaltan PF & 2 & \\
\hline & Sodatan TSN, Selic chemical company & 1 & \\
\hline & Sodium Formate (HCOONa) & 2 & $2 \times 30$ \\
\hline & Baking Soda $\left(\mathrm{NaHCO}_{3}\right)$ (Optional) & 0,5 & $2 \times 15$ \\
\hline \multirow[t]{2}{*}{ Retanning } & Acrylic Syntan (R40), Abhilash chemicals Pvt., Ltd., India & 6 & \multirow{2}{*}{60} \\
\hline & $40^{\circ} \mathrm{C}$ water & 70 & \\
\hline \multirow[t]{6}{*}{ Fatliquoring } & Water $50^{\circ} \mathrm{C}$ & 40 & \multirow{3}{*}{40} \\
\hline & Tannit LSW, Dr Bohme & 2 & \\
\hline & Seroil LL, Quimser S.A & 2 & \\
\hline & Garboil BS, Selic chemical company & 6 & \multirow[t]{3}{*}{30} \\
\hline & Coriol FBD & 4 & \\
\hline & Leathernol BLM, Allied chemicals international company limited & 2 & \\
\hline Fixating & Formic acid $(\mathrm{HCOOH})$ & 1,5 & $2 \times 30$ \\
\hline Antifungal & Antifungal agent & 0,05 & 30 \\
\hline Masking & Catalix GS, Clariant & 1 & 15 \\
\hline
\end{tabular}




\section{Analytical Procedures}

Physical Properties

The softness, tear strength, tensile strength, and elongation was determined. Measurement of softness used $20 \mathrm{~mm}$ diameter of the sample. Measurement of the physical properties was performed as per standard procedures $[16,17]$.

\section{Chemical Properties}

Chemical properties tests of crust leather were used to investigate the tannin bound and degree of tannage that were calculated using equations 1 and 2 .

Tannin bound $=100 \%-($ water content + fat content + water soluble subtances + insoluble ash + hide substances $) \%$

Degree of tannage $=\frac{\text { tannin bound }}{\text { hide substance }} \times 100 \%$

\section{Hydrothermal Stability}

Using DSC-60, the thermal denaturation of each sample was determined. The heating rate was maintained at $10^{\circ} \mathrm{C} / \mathrm{min}$. Sample weighed around $5 \mathrm{mg}$.

\section{Organoleptic Properties}

All of the samples were assessed for general appearance, grain smoothness, and fullness by hand and visual examination of three experienced tanners. Those tanners gave a score for each parameter on a scale of 0-10 points. Higher points mean better property.

\section{Scanning Electron Microscopy}

Scanning Electron Microscopy SEC type SNE $3200 \mathrm{M}$ was used to analyze samples before and after acid bating addition and crust leather samples. Samples were cut into specimens without pre-treatment and were coated with gold. The grain surface and cross section were obtained by SEM operation at an accelerating voltage of $15 \mathrm{kV}$.

\section{RESULTS AND DISCUSSIONS}

\section{Physical Properties}

From the Figure 1, it is observed that leather tanned with glutaraldehyde-gambir was the softest leather. Glutaraldehyde followed by gambir leather without rebating has a higher value of softness than that with rebating, while alum-gambir leather without rebating has a lower value of softness than that with rebating.

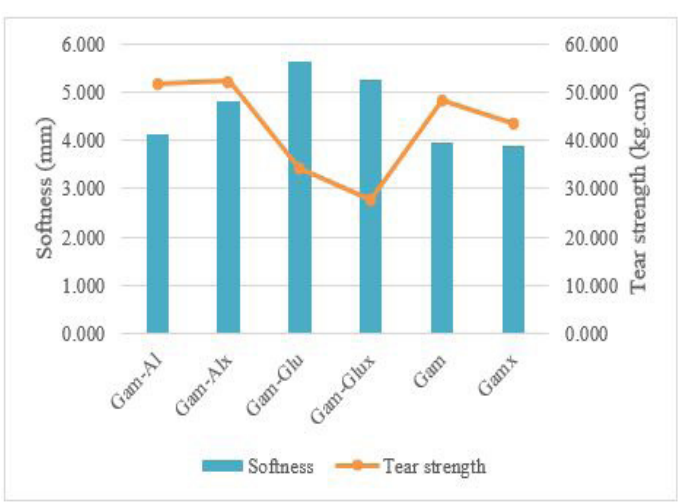

Figure 1. Graphical presentation of softness and tear strength of the leather samples

Crust leather from control leather and experimental leather showed different tear strength and given in Figure 1. Leather samples of alum followed by gambir showed the highest tear strength, while leather samples tanned with glutaraldehyde followed by gambir showed the lowest. From the same figure, it is observed that rebating slightly increased the tear strength of gambir followed by alum tanned leather. On the other hand, rebating decreased the tear strength of gambir-glutaraldehyde and control leather samples. Tear strength could be defined as the toughness of the leather because it is strongly correlated with the ability of leather to 'survive' from the tear [18]. Sizeland et al. [18] also found that tear strength is influenced by the strength perpendicular to the axis of fibril collagen which is affected by the strength of the cross-link. 


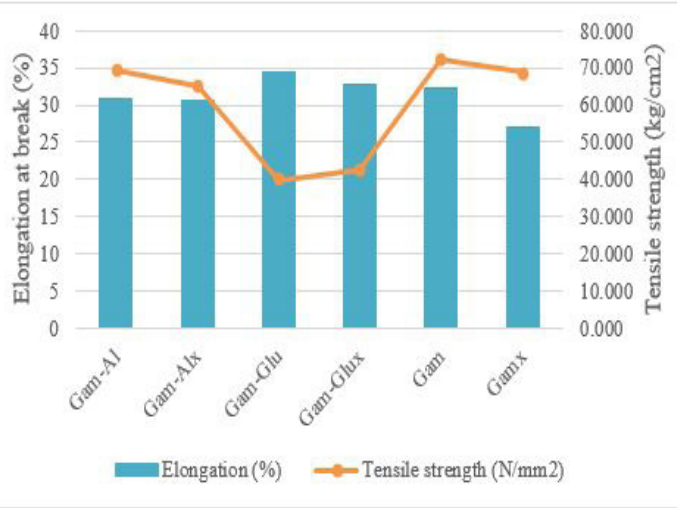

Figure 2. Graphical presentation of tensile strength and elongation of the leather samples

Leather tanned with gambirglutaraldehyde showed the highest tensile strength, while the elongation was the opposite. Graphical presentation in the Figure 2 also revealed that the tensile strength value of the leather tanned with gambir and glutaraldehyde were the highest. However, this combination showed the lowest elongation. Gambirglutaraldehyde tanned leather with rebating showed higher tensile strength value than that without rebating, while the other samples were the opposites. Elongation test results revealed that rebating decreased the elongation value of gambir-glutaraldehyde and control leather, whereas in the gambir-alum leather was almost equal.

Adding more bating agent in the leather making process could have two different effects, first, it can increase the quality of the leathers, and the second is the collagen could be overworked caused by the hydrolyzing effect of the bating agent on the collagen [11]. This study [11] also found that after bating stage, the fibres were separated and opening up. When the skin was added with more bating agent, the opening up was bigger and there were some fibrils splitting-up.

\section{Chemical Properties}

The chemical analysis result is given in Table 4. The hide/skin substance value is the quantification of the collagen (the skin protein). In the bating stage, non-fibrous protein, including collagen types that do not form collagen fibrils, were also removed [11]. Rebating means removing more interfibrillary protein in the skin.

Table 4: Analysis results of the chemical properties testing

\begin{tabular}{lrrrrrr}
\hline \multicolumn{1}{c}{ Parameter Uji } & Gam-Al & Gam-Alx & Gam-Glu & Gam_Glux & \multicolumn{1}{c}{ Gam } & Gamx \\
\hline Moisture (\%) & 11.66 & 11.02 & 13.57 & 11.78 & 12.92 & 11.17 \\
Insoluble ash (\%) & 1.110 & 2.020 & 1.39 & 1.085 & 1.250 & 1.430 \\
Fats/oils (\%) & 18.99 & 17.23 & 12.27 & 11.30 & 14.79 & 14.42 \\
Hide substance & 52.15 & 56.31 & 55.84 & 56.01 & 52.55 & 56.62 \\
Tannin bound (\%) & 14.29 & 12.51 & 14.55 & 18.65 & 17.31 & 14.85 \\
Degree of tannage (\%) & 27.42 & 22.22 & 26.06 & 33.3 & 32.95 & 26.22 \\
\hline
\end{tabular}

From the same table, it is clearly observed that the tannin bound and the degree of tannage were linear. Leather tanned with gambir followed by glutaraldehyde (rebated) showed the highest tannin bound and degree of tannage, whereas leather tanned with gambir followed by alum (rebated) showed the lowest. Rebating increased the tannin bound and the degree of tannage of gambir-glutaraldehyde leather, while in the gambir-alum and control leather decreased. The percentage of degree of tannage presents the tannin content in the leather that it could determine the stabilization of the chemicals in the collagen and affect the properties of the finished leather [19].

\section{Hydrothermal Stability}

Hydrothermal stability is one of the methods to measure the efficiency of the tanning process based on phase transition and denaturation process of the collagen using differential scanning calorimetry (DSC) [20]. All of the samples in this study have two peaks (Figure 3).

From the Figure 3 , all of the samples undergo thermal denaturation and it is clearly showed that rebating has an impact on the collagen stability of leather tanned with gambiralum (Figure 3(a)), gambir-glutaraldehyde (Figure $3(b))$, and gambir (Figure 3(c)). Compared with the literature [21], the thermogram peaks of all 
samples in this study were broader and narrower. It is showed that gambir, with or without tanning agent combination, has low tannin diffusion that caused diverse cross-linking [22]. DSC peak showed the unique population of the collagen molecules $[22,21]$. The broader the peak the broader the distribution of collagen molecules which have hydrothermal stability. Moreover, the two peaks of all the samples revealed that the collagen molecules distribution across the thickness of the leather has unequal thermal stability [22]

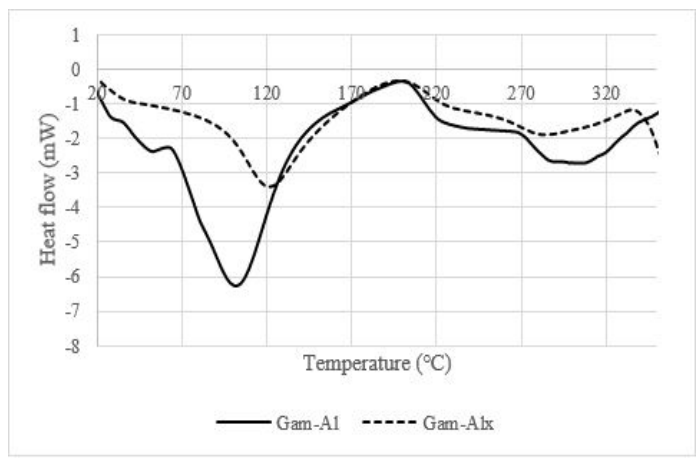

(a)

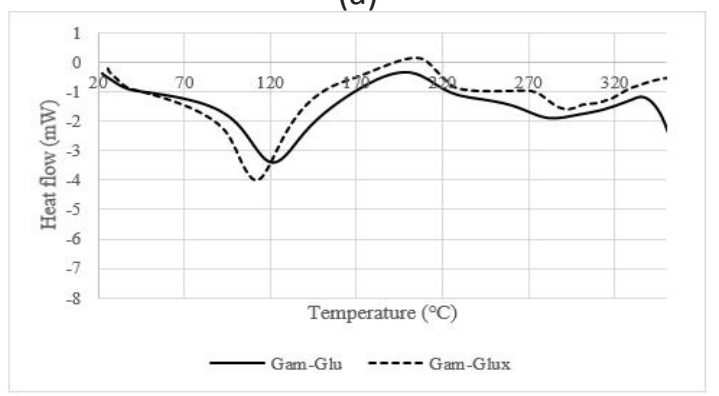

(b)

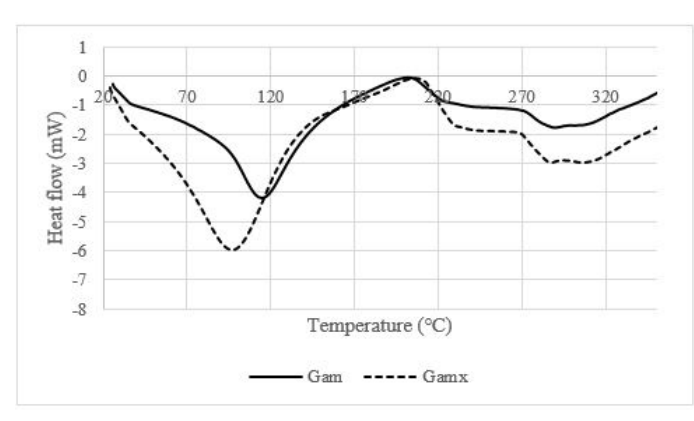

(c)

Figure 3. DSC thermogram of the rebated and unrebated leather samples (a) gambir-Alum; (b) gambir-glutaraldehyde; (c) gambir

Each peak has the temperature of denaturation called $\mathrm{T}_{\max }$ where the hydrothermal stability of the collagen is presented. On the other hand, the shrinkage temperature $\left(T_{s}\right)$ that usually used as the 'cook proof' in the leather tanning industry is the onset temperature $\left(\mathrm{T}_{i}\right)$ in the DSC [22]. From the Table 5, the first onset temperature varied between 65.9 and $99.06^{\circ} \mathrm{C}$. Rebated gambir-alum tanned leather was higher than that unrebated leather. However, gambirglutaraldehyde and control leather showed the opposites. Surprisingly, the unrebated gambir tanned leather revealed the highest onset temperature. For the second onset temperature, the gambir-glutaraldehyde tanned leather showed the highest value.

Table 5: Hydrothermal stability data of the samples using DSC

\begin{tabular}{lcccc}
\hline \multicolumn{1}{c}{ Sample } & $\mathrm{T}_{\text {onset1 }}\left({ }^{\circ} \mathrm{C}\right)$ & $\mathrm{T}_{\text {onset2 }}\left({ }^{\circ} \mathrm{C}\right)$ & $\mathrm{T}_{\max 1}\left({ }^{\circ} \mathrm{C}\right)$ & $\mathrm{T}_{\max 2}\left({ }^{\circ} \mathrm{C}\right)$ \\
\hline Gam-Al & 65.9 & 269.34 & 101.94 & 305.79 \\
Gam-Alx & 94.81 & 259.27 & 121.62 & 283.73 \\
Gam-Glu & 94.81 & 259.27 & 121.62 & 283.73 \\
Gam-Glux & 90.19 & 273.75 & 112.01 & 292.25 \\
Gam & 99.06 & 205.97 & 114.9 & 289.2 \\
Gamx & 77.17 & 269.31 & 96.65 & 306.72 \\
\hline
\end{tabular}

The higher the denaturation temperature $\left(T_{\text {max }}\right)$, the more stable the skin collagen. Rebated gambir-alum tanned leather showed higher $T_{\max 1}$ than the unrebated one, while other samples showed the opposites. Gambir-alum leather with rebating showed the same DSC parameters value with gambir-glutaraldehyde leather without rebating. In the tanning process, aluminum salt performed weaker and longer covalent bond with the collagen, unstable, and easily hydrolyzed [20]. 


\section{Organoleptic Properties}

The combination tanning agent affected the color of the crust leather. From Figure 4, it is clearly seen that the grain surface of gambir- glutaraldehyde leathers were the smoothest ones with less looseness than others. While the gambir leather with rebating was the darkest and unclear surface.

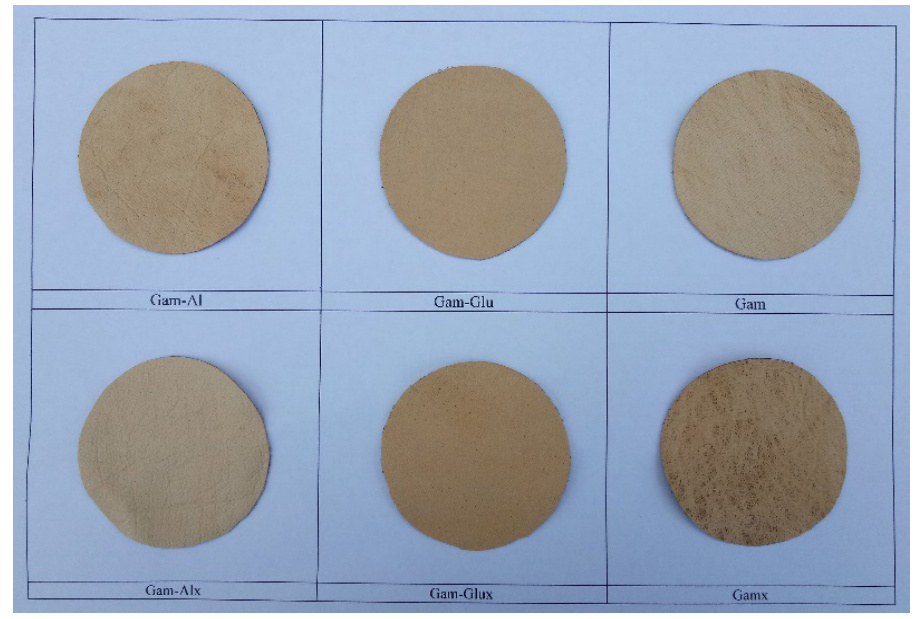

Figure 4. Gambir tanned leather

The organoleptic properties of crust leathers from the experiment are presented in the Figure 5. From the graphical presentation, the gambir-glutaraldehyde leather without rebating was the softest. It was similar to the softness testing results. From the same figure, it is shown that unrebated gambir-glutaraldehyde leather exhibited better fullness than other samples, whereas rebated gambir-glutaraldehyde leather exhibited better grain smoothness and general appearance.

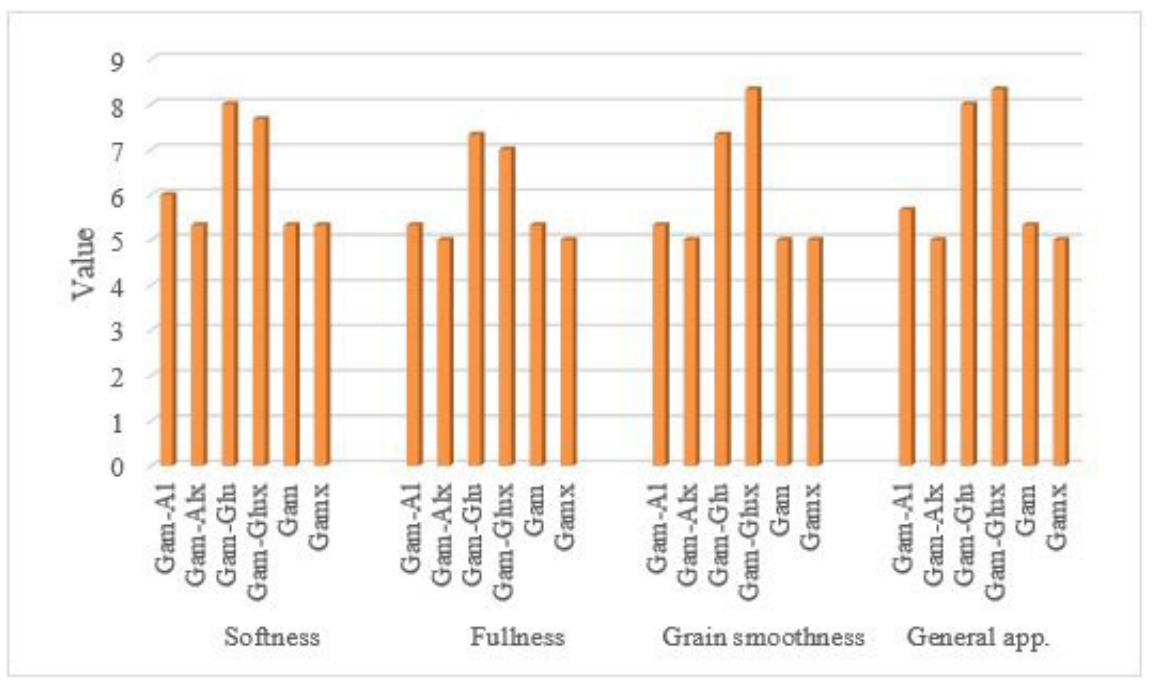

Figure 5. Graphical presentation of organoleptic properties of the leather samples

\section{Scanning Electron Microscopy Analysis}

Scanning electron micrograph of the samples is shown in Figure 6(a)-(f) to investigate the grain characteristics. It is seen that the grain surface of crust leather at a magnification of $X 80$ was clean without tannin deposition. The pores of all the leather samples were clearly visible but the gambir-glutaraldehyde tanned leather. The grain surface of gambir-glutaraldehyde (Figure $6(c)$ and 6(d)) tanned leather was smoother than others. The pores of Gam-Alx leather (Figure 6(b)) were smaller and neater than Gam-Al. The grain surface of gambir-alum tanned leather (Figure 6(a) and (b)) also looks smoother than gambir tanned leather (control). 


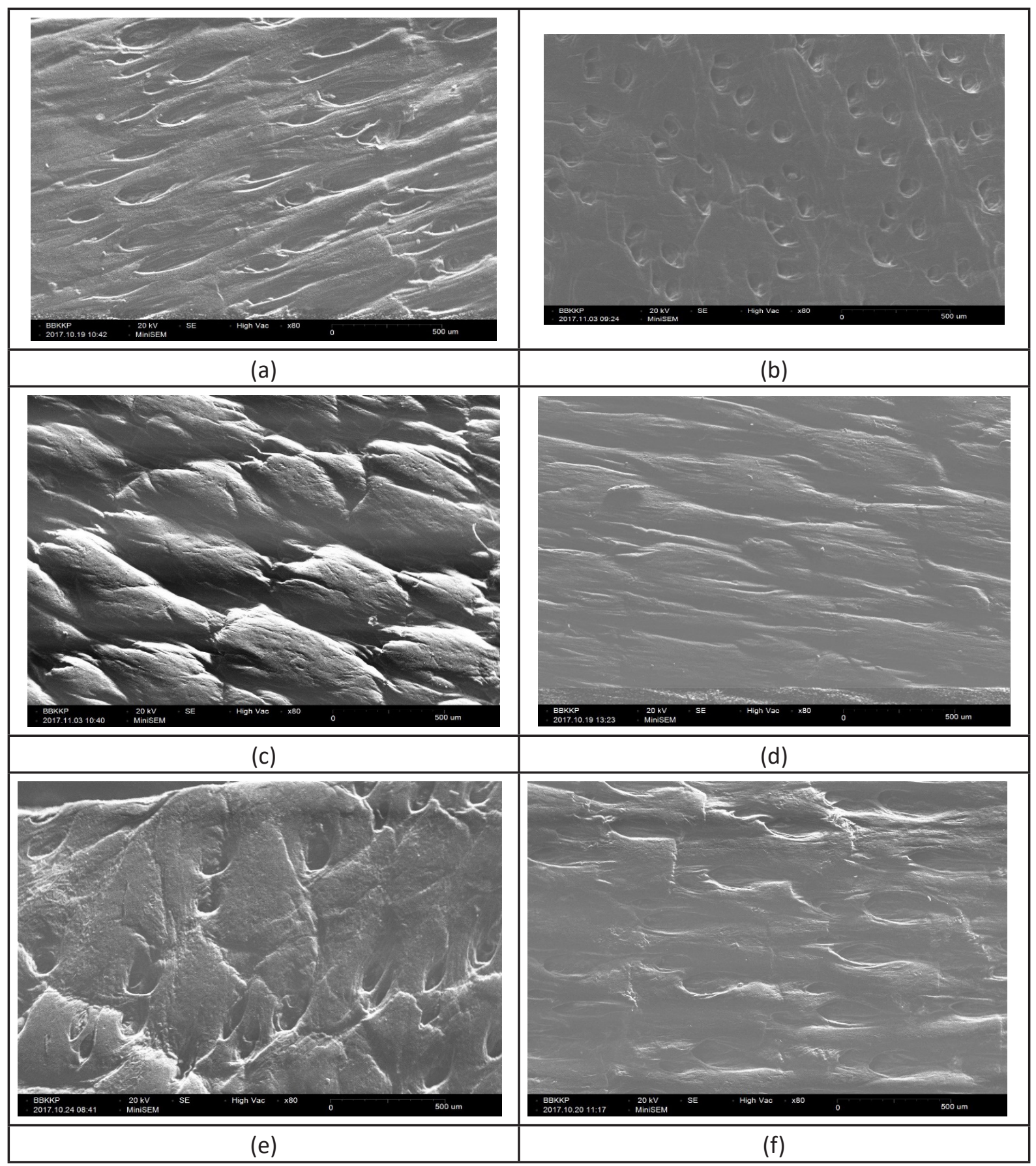

Figure 6. Scanning electron micrograph of the grain surface $(80 \mathrm{X})$ of leather samples:

(a) Gam-Al; (b) Gam-Alx; (c) Gam-Glu; (d) Gam-Glux; (e) Gam; (f) Gamx

\section{CONCLUSIONS}

Gambir (Uncaria gambier) is a traditional plant from West Java, Indonesia which contains tannin to offer environmentally benign leather tanning methodology. This study reported that rebating using acid bate before repickling increased softness, tear strength, and hydrothermal stability of gambir-alum tanned leather. Alum has weaker covalent bond with skin collagen that rebating helped the fiber to split up to strengthen the interaction with skin collagen. Even though gambir-glutaraldehyde tanned leather showed the best organoleptic properties, rebating only increased its tensile strength, degree of tannage, and tannin bound. The broad DSC peak revealed that the distribution of tanning agent molecules of all samples was not 
uniform. In this study, rebating could increase and decrease the quality of leather.

\section{REFERENCES}

1. Firdaus, F., Dahlan, M.H., Faizal, M., Kaprawi, K., Arita, S., Study of local west sumatera stove performances in boiling gambir (Uncaria Gambir Roxb.), J Sustain Dev, 2015, 8, 1, 2529, https://doi.org/10.5539/jsd.v8n1p252.

2. Kassim, M.J., Hussin, M.H., Achmad, A., Dahon, N.H., Suan, T.K., Hamdan, H.S., Determination of total phenol, condensed tannin and flavonoid contents and antioxidant activity of Uncaria gambir extracts, Majalah Farmasi Indonesia, 2011, 22, 1, 50-9.

3. Kasim, A., Asben, A., Mutiar, S., The study of gambir quality and its relationship with characteristics of tanned leather (in Indonesia), Majalah Kulit, Karet, dan Plastik, 2015, 31, 1, 55-64, https://doi.org/10.20543/ mkkp.v31i1.220.

4. Arel, A., Gambir galamai (black cube) manufacturing using microwave oven, Scientia, 2015, 5, 1, 1-5, https://doi. org/10.36434/scientia.v5i1.60.

5. Irianty, R.S., Yenti, S.R., Effect of ethanolwater solvent ratio on levels of tannins in leaves gambier socletation (in Indonesia), Sagu, 2014, 13, 1, 1-7.

6. Castell, J., Sorolla, S., Jorba, M., Aribau, J., Bacardit, A., Olle L., Tara (Caesalpinia spinosa): The sustainable source of tannins for innovative tanning processes, J Am Leather Chem Assoc, 2013, 108, 6, 200-49.

7. Musa, A., Aravindhan, R., Madhan, B., Rao, J., Chandrasekaran, B., Henna-aluminum combination tannage: a greener alternative tanning system, J Am Leather Chem Assoc, 2011, 106, 6, 190.

8. Combalia, F., Morera, J.M., Bartoli, E., Study of several variables in the fixation stage of a vegetable tannage after penetration under ultrasound, J Am Leather Chem Assoc, 2018, $113,5,134-41$.
9. Kasim, A., Nurdin, H., Mutiar, S., Application of Gambier as a tanning agent through the implementation of tanning combination (in Indonesia), Jurnal Litbang Industri, 2012, 2, 2, 55-62. https://doi.org/10.24960/jli. v2i2.600.55-62.

10. Kite, M., Thomson, R., Conservation of Leather and Related Materials, Routledge, 2006, https://doi.org/10.4324/9780080454665.

11. Haiyan, D., Chengjian, L., The action of pancreatin on colagen fibres and interfibrillary substance during bating, I Soc Leather Technol Chem, 2006, 90, 47-53.

12. Al Mamun, Md. A., Khan, Md. M., Akand, Md. N.R., Khan, S.N., Hoq, Md. M., Characterization of an alkaline protease with high quality bating potential in leather processing from Bacillus licheniformis MZK05M9 mutant, International Journal of Biological Rsearch, 2015, 3, 1, 36-41, https://doi.org/10.14419/ ijbr.v3i1.4250.

13. Pertiwiningrum, A., Anggraini, F.D., Fitrianto, N.A., Rochijan, R., Isolation and identification of bacterial protease enzyme of leather waste, $J$ Indones Trop Anim Agric, 2017, 42, 1, 33-41. https://doi.org/10.14710/jitaa.42.1.33-41

14. Sizeland, K.H., Edmonds, R.L., Basil-Jones, M.M., Kirby, N., Hawley, A., Mudie, S., Haverkamp, R. G., Changes to collagen structure during leather processing, J Agric Food Chem, 2015, 63, 9, 2499-505, https:// doi.org/10.1021/jf506357j

15. Sreeram, K.J., Aravindhan, R., Raghava Rao, J., Nair, B.U., Development of natural garment leathers: A metal free approach, J Am Leather Chem Assoc, 2010, 105, 6, 401-9.

16. International Organization for Standardization, ISO 3376: 2011 (IULTCS/ IUP 6) Leather - Physical and Mechanical Test - Determination of Tensile Strength and Percentage extension, Geneva, Switzerland, 2011.

17. International Organization for Standardization, ISO 17235:2015 (IULTCS/ 
IUP 36) Leather - Physical and Mechanical Tests - Determination of Softness, Geneva, Switzerland, 2015.

18. Sizeland, K.H., Basil-Jones, M.M., Edmonds, R.L., Cooper, S.M., Kirby, N., Hawley, A., Haverkamp, R.G., Collagen orientation and leather strength for selected mammals, J Agric Food Chem, 2013, 61, 4, 887-92, https://doi.org/10.1021/jf3043067.

19. Canals, T., Morera, J.M., Combalía, F., Bartolí, E., Application of Infrared Spectroscopy (FTIR and NIR) in Vegetable Tanning Process Control, J Soc Leather Technol Chem, 2014, 97, 3, 93-100.

20. Onem, E., Yorgancioglu, A., Karavana, H.A., Yilmaz, O., Comparison of different tanning agents on the stabilization of collagen via differential scanning calorimetry, J Therm Anal Calorim, 2017, 129, 1, 1-8, https://doi. org/10.1007/s10973-017-6175-x.
21. Carşote, C., Badea, E., Miu, L., Della Gatta, G., Study of the effect of tannins and animal species on the thermal stability of vegetable leather by differential scanning calorimetry, $J$ Therm Anal Calorim, 2016, 124, 3, 1255-66, https://doi.org/10.1007/s10973-016-5344-7.

22. Tang, H.R., Covington, A.D., Hancock, R.A., Use of DSC to Detect the Heterogeneity of Hydrothermal Stability in the PolyphenolTreated Collagen Matrix, J Agric Food Chem, 2003, 51, 23, 6652-6, https://doi. org/10.1021/jf034380u.

(C) 2019 by the author(s). Published by INCDTP-ICPI, Bucharest, RO. This is an open access article distributed under the terms and conditions of the Creative Commons Attribution license (http://creativecommons.org/licenses/ by/4.0/). 